\title{
Influence Research of Science and Technology Innovation Team Building on the Innovation of Engineering Graduation Design
}

\author{
Jia YAO, Wei LU, Lili MA \& Ping HAN \\ College of Mechanical Engineering, Jiamusi University, 154007, Jiamusi, China
}

\begin{abstract}
Based on the analysis of current situation and development trend of science and technology innovation team in colleges and universities, the suggestions that the cultivation of innovative talents should better depend on the development of science and technology innovation team have been put forward, the performance of innovation projects and the cultivation of innovation ability should be practiced in graduation design tache for undergraduates. Making students better use the innovative thinking, cultivate the practical ability, study the innovation thought, so that the practical problems can be solved in the completion of projects. Under the guidance mode of multi-tutor cultivation from the innovation team, and under the sufficient experimental and practical conditions, better qualified outstanding graduates can be provided for the society with the innovation ability and practical ability.
\end{abstract}

KEYWORD: Science and technology innovation team; Graduation design innovation; Innovation talents

\section{CURRENT SITUATION OF UNIVERSITY SCIENCE AND TECHNOLOGY INNOVATION TEAM CONSTRUCTION}

\subsection{Current situation of science and technology innovation team}

Science and technology innovation team is defined as the innovation research group, which is under the leader of outstanding talents, with excellent talented persons as the backbone of middle-aged and young, carry out the basic research and applied research at a certain academic field around an innovation research direction (Yang et al. 2009). The current major breakthrough of science frontiers and the significant original scientific research achievements, are the mostly results of the multi-disciplinary crossover, which suggest the interdisciplinary have become the inevitable trend of scientific development. The subsidizing pattern of science and technology innovation team provides conditions for the crossover and the penetration of different subjects, promotes the innovative thinking sparks and eventually forms innovation fruits (Chen 2010). Therefore, in recent years, countries around the world have stepped up for science and technology innovation team's support and assistance. But in our country, the science and technology innovation team start late and the funding mechanisms and management ways exist many problems and shortcomings, therefore, draw lessons from foreign science and technology innovation team support experience, set up our country science and technology innovation team support strategic target, improve the science and technology innovation team funding mechanism, strengthening science and technology innovation team support work, all can provide a strong talent guarantee for constructing a creative country and intellectual support. How to make full use of the resources of the science and technology innovation team, beneficially push the teaching and research of the undergraduates, is the research direction of this paper.

\subsection{Status and development of science and technology innovation team in universities}

At present, science and research innovation teams are rising in various universities, science and research team construction is playing an important role on the scientific research in colleges and universities, also playing a positive role on the formation of the new teaching patterns. Innovation is the soul and unremitting power of scientific and technological progress, but the personal power is trivial, by means of the innovation team building, can 'accumulate small steps so that thousands of miles, small flows into a river'.

The importance of science and technology innovation team on the construction and development of higher universities mainly embodied 
in the following points: 1 . The establishment of science and research team can effectively enhance the discipline level, promote the discipline development, push the development of the scientific research project, which are all advantageous to the strengthen of the disciplinary power; 2. Team building can effectively promote the innovative ideas and results, innovation team members works together, integrate the intellectual resources effectively, can create a more practical innovation achievements; 3 . The mechanism of science and research team, can promote the ability of the team researchers further, promote the healthy growth of the scientific research personnel. University science and research innovation team is composed of the scientific research personnel, teaching backbone and experimentalist as a combination team, therefore, has certain advantages on the accumulation of knowledge and practice ability and teaching ability. The advantage is obvious making science research innovation team as the carrier of the guidance of graduation design for students, because science and research innovation team possess the integration of innovative thinking, innovative projects, experimental conditions and practical skills. Therefore, it is meaningful to require students to carry out graduation design based on the support of the science and research innovation team.

\section{TRAINING OF PRACTICAL ABILITY AND INNOVATION ABILITY OF UNDERGRADUATES}

\subsection{Cultivate senior specialized talents with innovative spirit and practice ability}

Practice teaching is an important part of engineering education and the important way to improve students' comprehensive quality and cultivate students' practical ability. Practice teaching in the teaching type college has a special important position for the engineering talents cultivation. Due to the constraints of traditional education thought, there are many drawbacks for the pattern of higher education, such as lack of expertise and innovation ability of students, emphasizing on theory but ignoring the practical ability. The practice experiences prove that great importance should be attached to the knowledge structure of talents and the cultivation of the scientific quality, also attach to the cultivation of practice ability and creative ability. College students' science and technology innovation talents should possess solid theoretical foundations, extraordinary innovation concept, keenly innovative thinking, the innovation of the basic skills and excellent innovation personality.

In gerenal, innovative concept can be described as the innovation spirit, including promoting innovation, pursuit innovation and innovative consciousness. Only under the incentive of a strong sense of innovation and the guidance of innovation spirit, college students can produce strong innovation incentives. Therefore, the atmosphere caused by the innovation consciousness and innovation spirit of science and research innovation team is the prerequisite of innovation and motivation of college students. Innovative thinking is a thought process, refers to the invention or discovery of a new way to solve new problems. Innovative thinking is an important quality of innovative talents; Innovation skill is action ability can reflect innovation subjects, it is the carrier of innovative ideas performance and the key of innovative talent training; Innovation personality is an innovation personality traits formed by long-term stable and lasting innovation education and training, is the ultimate goal of cultivating innovation personnel.

Graduation design is the last important comprehensive practice teaching tache during the period of college, can cultivate students to use the basic theory, basic knowledge and basic skill they have learned to analysis actual problem, foster independent working ability and innovative consciousness. With an increasingly competition under the increasing requirement of innovative ability and practical work ability, it is very necessary for college students to strengthen their innovation ability of science and technology, becoming a qualified talent with innovative concept, innovative thinking, innovation skill, innovation personality through the graduation design tache, to perfect their knowledge structure and quality structure, so as to adapt to the development of the society.

\subsection{Necessity of graduation design innovative cultivation and improvement of employment competitiveness}

Graduation design is an important teaching tache for the cultivation of engineering applied professional talents, which can not only cultivate students' comprehensive ability by using knowledge to solve actual problems, but also can exercise the students' team cooperation spirit and innovation ability. In order to adapt to the new situation of competition for jobs, engineering applied professional talents should be timely change ideas, to suit for the strengthen reform of the graduation design. From the graduation design topic selection and the combination of study and practical using aspects, the level of students' graduation design can be improved, the innovative cultivation can be performed and the employment competitiveness can be improved. 


\section{THE INTERACTIONS OF SCIENCE AND TECHNOLOGY INNOVATION TEAM AND GRADUATION DESIGN INNOVATION}

Graduation design for engineering use is a comprehensive professional knowledge training, the cultivation of innovation ability of the major part students can be realized by this opportunity, therefore, the common-share of teachers and the financial support of innovative team will be great help to improve the quality of graduation. The combination of both science and technology innovation and graduation design is benefit for the two to the maximum level. Cross complementarities of the two can make scientific research team building be linked with practical teaching link, rather than separated from it.

Based on the policy support and financial support of science and technology innovation team, the scientific research projects and the project's actual operation can be performed, undergraduates can take advantage of this opportunity to study the innovative projects in-depth, common sharing the team teachers and getting different professional technical support from special personnel.

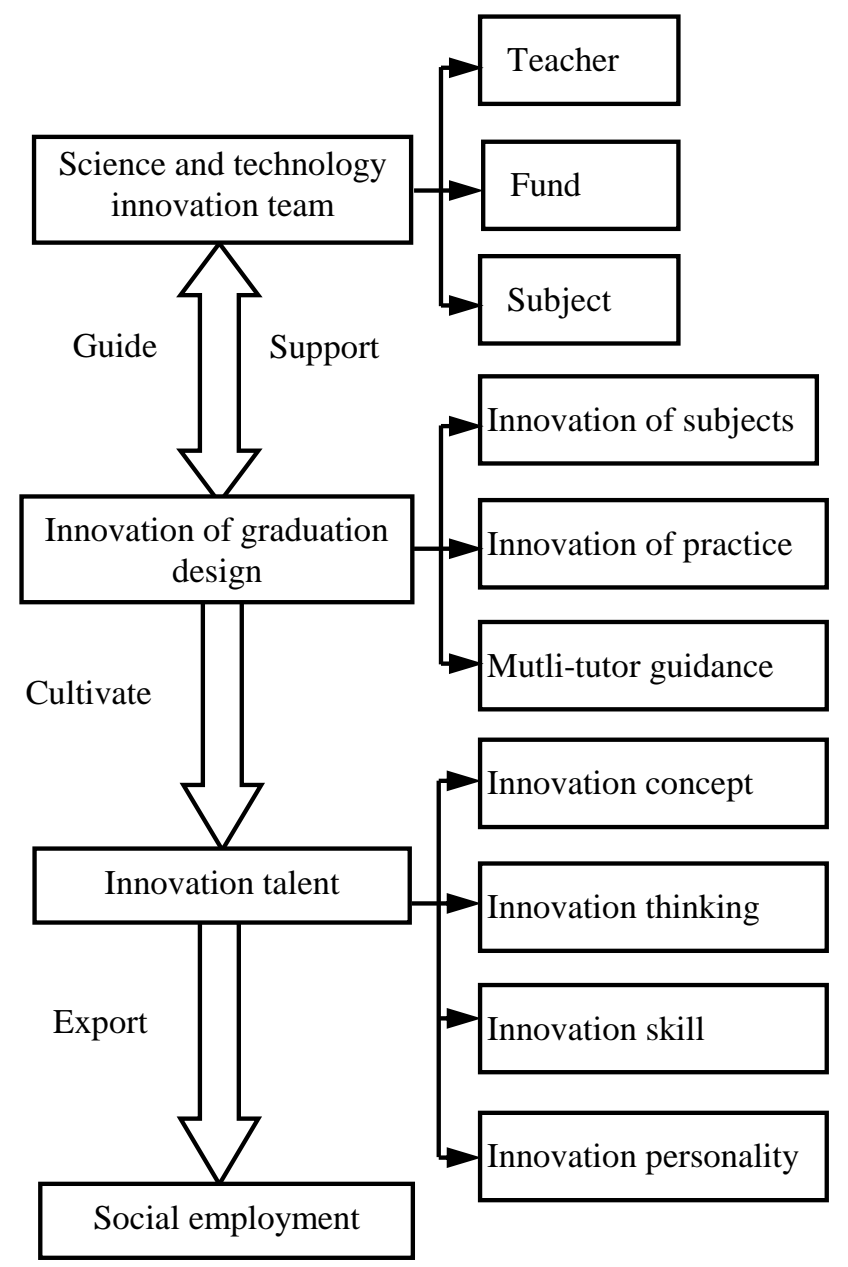

Figure 1. Relationship between the innovative graduation design and science and technology innovation team

As in Fig.1, the advantages of science and research innovation team are strong teaching staff, adequate financial support, diversity and practical scientific research projects. Graduation design innovation requires sufficient available project funds. The projects can be smoothly carried out under the rich funding; the experiment performance is closely related to the quality of graduation design. Students can publish the scientific research papers and apply for national patents under certain funding, to better protect their own innovative ideas and scientific research, generating social influence and proving the person ability. Science and research innovation team have diversity and practical scientific research projects, so that can realize the diversity and innovation of graduation design. For the projects must complete under the innovative thinking, the students' understanding of the innovative theory will be more profound, and innovative practice will also be targeted. The science and research innovation team has a strong teaching staff, to make teachers better play a role in guiding, the knowledge comprehensive degree of a single teacher is restricted, and the realization of the creative project and thinking is intercrossing with multiple disciplines and fields of knowledge. Therefore, the guidance of innovative team teachers for the undergraduates will be more comprehensive and effective. Students can gain more knowledge from different teachers' sources and more comprehensive guidance. Practice has proved that strengthening the guidance of graduation design topic selections, executing mutli-tutor mode, can improve the quality of graduation design and the important measure to promote students' employment ability (Yao et al. 2014). For individual students, to become a qualified innovation talents, requiring to form a more perfect innovative thinking ability in the stage of undergraduate study, especially through the practice tache of graduation design, by joining the scientific research innovation team, will be better able to acquire comprehensive use knowledge ability and more practical opportunities. Undergraduates can better get ability cultivation with innovative concept, innovative thinking, innovation skill, innovation personality, and become qualified practical and innovative talents, eventually lay the solid foundation for employment and enter the society.

\section{INNOVATION RESULTS OF GRADUATES UNDER THE GUIDANCE OF SCIENCE AND TECHNOLOGY INNOVATION TEAM}

Taking Jiamusi university mechanical engineering college as example, under the guidance of jiamusi university of science and technology innovation team, graduates are organized to participate in national, provincial science and technology innovation contest, winning more than 80 awards in 
2014, as shown in Fig. 2. The scientific research projects are with broad range of topics, such as intelligent household medicine cabinet, multifunction desk and a blackboard, environmental protection sewage secondary use of toilet with new materials, also a farm corn straw baling machine and so on. The projects are under the guidance of the science and research innovation team with technology and fund support, by use the development of science and research innovation team as an opportunity, graduates can develop the actual research results of the projects, and become qualified innovation talents.
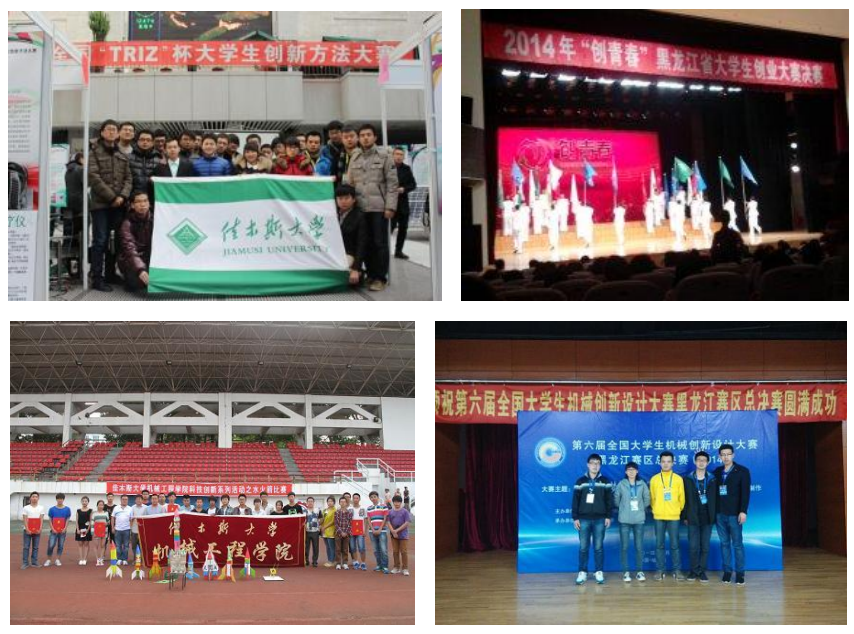

Figure 2. Various innovation competition photos of graduates

\section{CONCLUSIONS}

Make full use of the teachers advantage and financial support of university science and research innovation team, and better integrate the graduate design with scientific research innovation team project, can guiding undergraduate graduation design. The combination of both, can make both benefit maximum level. Cross-complementarities role of the two, can make science and research team building cannot be separated from practical teaching tache. Better cultivating of the innovation ability, can make the new generation of college students' become the excellent innovative talents with innovation thinking and innovation ability, promote the innovation industrialization of the society.

\section{ACKNOWLEDGEMENT}

This project was supported by Jiamusi university of science and technology innovation team building program (Cxtd-2013-01); Heilongjiang province colleges and universities educational reform project (JG2013010521) and Jiamusi university teaching research special project (JYLA2012-018).

\section{REFERENCES}

[1] Yang, Z. R, Ju, Y. Q. Li,Y.Z. 2009. The Change of the Innovation Theory and Building of Science and Technology Innovation Team in Our Country, Gansu Social Sciences 3:239-242.

[2] Chen,Y. Y. 2010.Training High Level Innovation Team to Serve the Construction of an Innovative Country, National Natural Seience foundation of China 5:257-259.

[3] Yao, J. Lu, W. Ma, L.L. Li, C.H. Han, P. 2014.Standardization of the Management of Engineering Graduate Design Ability Training and Employment, China Electric Power Education, 18 (313): 71-72. 